\section{Concentration of Inhaled Cerium-I44 in Pulmonary Lymph Nodes of Human Beings}

Is the course of an investigation of fission products deposited in human lungs ${ }^{1}$, we have also measured the radioactivity of pulmonary lymph nodes. In most cases investigated so far, the amounts of fission products found were too small to permit deductions about concentration of these substances in the lymph nodes. However, in some cases larger activities were observed and the occurrence of a concentration process could be clearly recognized.

Concentration of radioelements in lymph nodes may, in certain circumstances, produce high local radiation dosages. In evaluating radiation hazards due to inhaled radioelements it is therefore necessary to find out whether lymph nodes have to bo considered as a 'eritical organ'. Many factors must be taken into consideration in this connexion ${ }^{2,3}$, but the data required for this are only partly available so far. Data about the concentration of inhaled radioelements in lymph nodes of human beings have been reported only in one case, that of a man who had occupationally inhaled plutonium-containing aerosols for several years ${ }^{5}$. Further data on concentration in lymph nodes have been obtained in experiments with animals, chiefly with plutonium and polonium $2,3,5,6$.

We wish to report three cases, in which our measuremonts give information about concentration of cerium-144 in human lymph nodes (Table 1). The lungs investigated were obtained from deceased persons, who had-like all people-inhaled the radioactive aerosol produced in nuclear test explosions in recent years. The major part of the cerium-144 detected in our measurements on lungs was probably produced in the high-yield test explosions carried out in 1957 and 1958. Cerium-144 is particularly suited for studying the behaviour of inhaled 'fall-out' particles for the following reasons: (1) This fission product is present in fall-out largely in insoluble

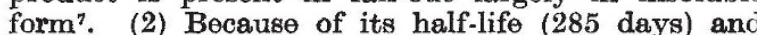
fission yield, cerium-144 is present in larger activity than other fission products in the period of approximately 1 4 years after formation by nuclear fission (ref. 8).

The organs investigated came from older persons (58-81 years), who had lived in Vienna for at least several years and died here. After the routine autopsy pulmonary lymph nodes (Lymphonodi bronchopulmonales, bifurcationis, tracheobronchiales, paratracheales) were removed. This was facilitated by their dark coloration due to deposited anthracotic pigment, which is commonly present in city inhabitants. Lymph nodes and lungs were then ashed separately. In the ashes cerium-144 $(E \gamma=$ $134 \mathrm{keV}$.) was determined by gamma-spectrometry using a well-type $\mathrm{NaI}(\mathrm{Tl})$-erystal. The spectrum was obtained in detail from 84 to $156 \mathrm{keV}$. by measuring $32 \mathrm{~min}$. in each channel of $8-\mathrm{keV}$. width. In the cases reported here, the photo-peak at $134 \mathrm{keV}$. was clearly identified. We determined the area of the photo-peak above a 'background continuum', due in large part to the Compton continua of other radioelements and. environmental radiation, and then calculated the amount of cerium-144 present by comparing with samples of known activity.

In the first group of samples listed in Table 1, the lymph nodes from three lungs were combined in order to increase the activity to be measured. Thus
Table 1. Cerium 144-Contents in LUxgs aND LYMPE Nodes

\begin{tabular}{|c|c|c|c|c|c|c|}
\hline $\begin{array}{r}\text { Date of } \\
\text { death }\end{array}$ & Sample* & $\begin{array}{c}\text { Wet } \\
\text { tissue } \\
\text { mass, } \\
W \\
(\mathrm{gm} .)\end{array}$ & $\begin{array}{c}\text { Ash } \\
\text { mass } \\
\text { (gm.) }\end{array}$ & $\begin{array}{l}\text { Date of } \\
\text { measure- } \\
\text { ment }\end{array}$ & $\begin{array}{l}\text { Cerium-144 } \\
\text { activity of } \\
\text { whole } \\
\text { sample, } A \\
(\mu \mu \mathrm{e}) \text { \&nd } \\
\text { statistical } \\
\text { error } \dagger\end{array}$ & $\begin{array}{l}\text { Ratio of } \\
\text { speciflc } \\
\text { activities } \\
\text { (lymph } \\
\text { nodes: } \\
\text { Iung) } \\
V \ddagger\end{array}$ \\
\hline & $\mathrm{BI} / \mathrm{N}$ & 45 & $2 \cdot 8$ & $14 / 12 / 60$ & $16.4 \times$ & \\
\hline $\begin{array}{l}29 / 11 / 60 \\
30 / 11 / 60 \\
29 / 11 / 60\end{array}$ & $\begin{array}{l}\text { BH/L } \\
\text { BG/L } \\
\text { BF/I } \\
\text { Sum }\end{array}$ & $\begin{array}{r}800 \\
500 \\
1,000 \\
2,300\end{array}$ & $\begin{array}{r}7 \cdot 46 \\
6 \cdot 68 \\
11 \cdot 39\end{array}$ & $\begin{array}{l}13 / 12 / 60 \\
13 / 12 / 60 \\
19 / 12 / 60\end{array}$ & $\begin{array}{l}17 \cdot 0 \\
16.5 \\
10.2 \\
43.7 \times \\
(1 \pm 0.80)\end{array}$ & 19 \\
\hline $17 / 8 / 60$ & $\mathrm{BQ} / \mathrm{N}$ & 11 & 0.15 & $13 / 2 / 61$ & $6.6 \times$ & \\
\hline $17 / 8 / 60$ & BP/I & 1,020 & $10 \cdot 1$ & $21 / 2 / 61$ & $\begin{array}{c}52 \cdot 0 \times \\
(1 \pm 0.23)\end{array}$ & 12 \\
\hline $12 / 5 / 60$ & $\mathrm{CG} / \mathrm{N}$ & 5 & $0-25$ & 11/ $2 / 61$ & $\begin{array}{c}5 \cdot 6 \times \\
(1 \pm 0.76)\end{array}$ & \\
\hline $12 / 5 / 60$ & $\mathrm{CF} / \mathrm{L}$ & 1,150 & $11 \cdot 8$ & $24 / 2 / 61$ & $\begin{array}{c}20.0 \times \\
(1 \pm 0.68)\end{array}$ & 64 \\
\hline
\end{tabular}

*/N, lymph nodes; /L, Iung.

† From calibration measurements for cerium-144: 1 c.p.m. $=$ $5 \cdot 1 \mu \mu \mathrm{c}$. Formula for calculation of statistical error, $\sigma$ :

$\sigma=\sqrt{4\left(A_{96}+A_{188}\right)^{2}}+\left(\overline{\left.A_{130}+A_{198}+A_{180}+A_{148}\right)^{2}}\right.$ (c.p.m.) where $A_{E}$ stands for the counts accumulated (in $32 \mathrm{~min}$.) in the channel between $(E-4) \mathrm{keV}$, and $(E+4) \mathrm{keV}$.

$\ddagger V=\frac{A N: W N}{A L: W L}$

the concentration ratio observed for this group of samples represents a mean value for three individuals. In the two other groups listed, activities of lung and lymph nodes of one individual were compared. As shown in the last column but one, the cerium-144 activities found in the lymph nodes were between $1 / 8$ and $1 / 3$ of the activities of the lungs. Since the mass of the lymph nodes is quite small, the specific activity (concentration of radioelement) in these organs is many times greater than in the remainder of the lung. The concentration ratios calculated are given in the last column. Because of the statistical error of the measurements, the values are only approximate; but it is apparent that an increase in specific activity of one to two orders of magnitude has occurred. Rather similar values were found in the investigations cited above ${ }^{8-6}$.

We thank Primaria B. Uiberrak (Prosektur "Am Steinhof") for putting the lungs at our disposal, Dr. H. Houtermans (International Atomic Energy Agency) for calibrating a cerium-144 solution and Mrs. Ch. Friedmann for ashing the samples. Prof. H. Hayek, director of the Institute for Anatomy, has kindly advised and supported us.

This investigation is being carried out under a research contract with the International Atomic Energy Agency.

\section{K. LIEBSCHER}

T. SCHÖNFELD

Institute for Inorganic Chemistry, University of Vienna,

\section{A. Schalder}

Institute for Anatomy,

University of Vienna.

1 Sehönfeld, T., Liebscher, K., Karl, F., and Friedmann Ch., Nature, 185, 192 (1960)

Casarett, I. J., Health Phys., 2, 379 (1960)

s Stannard, J. N., Proc. Sec. U.N. Intern. Conf. Peaceful $D_{\text {ses Atomic }}$ Energy, Geneva, 23, 306 (1958).

- Foreman, H., Moss, W., and Langham, W., Health Phys., 2, 326 (1960). - Bair, W. J., in Inhaled Particles and Vapours, Davies, C. N., ed., 162 (Proc. Symp., Oxford, May 1960) (Iondon, 1961).

- Morrow, P. E., and Casarett, L. J., in Inhaled Particles and Vapours, Davies, C. N., ed., 167 (Proc. Symp., Oxford, May 1960) (London, 1961). "Liebscher, K., Habashi, F., and Schonfeld, T., Atompraxis, 7, 94
(1961).

'Hunter, H. F., and Ballou, N. E., Nucleonics, 9, No. 5, C-2 (1951). 